\title{
MYENGLISHLAB AS AN EFFECTIVE COMPONENT OF BLENDED LEARNING APPROACH IN ENGLISH LANGUAGE TEACHING
}

Summary. The paper focuses on the blended learning approach represented by an online component MyEnglishLab developed by Pearson. It is one of the most up-to-date digital tools for blended learning that provides students with various English language activities in an interactive and engaging environment; gives access 24/7 through Pearson English Portal to complete tasks; supports instant feedback; contains video and audio activities, tests and practice exercises. MyEnglishLab allows teachers to be more informed about students' strengths and weaknesses. Each activity that students complete is recorded on MyEnglishLab Grade book, making it easy to see students' progress. The teacher can also find out which errors are common among students, using the Common Error Report. This modern and powerful resource changes the traditional approach of teaching a foreign language, makes the learning process more effective and diversified, significantly improves the quality of language teaching and makes a positive impact on learning outcomes.

Keywords: blended learning, MyEnglishLab, learning environment, the English language, digital tools.

Сабат C.I.

Національний університет «Львівська політехніка»

\section{MYENGLISHLAB ЯК ЕФЕКТИВНИЙ КОМПОНЕНТ ЗМІШАНОГО НАВЧАННЯ ПРИ ВИКЛАДАННІ АНГЛІЙСЬКОЇ МОВИ}

Анотація. У статті розглядається ефективність використання віртуальної навчальної платформи MyEnglishLab як важливого компонента змішаного навчання англійської мови. Це один з найсучасніших інструментів для Blended Learning (змішаного навчання, який передбачає використання традиційного підручника в поєднанні з інтерактивними завданнями онлайн).Такий формат максимально наближуе процес вивчення англійської мови до сучасних реалій, пропонуе різноманітну діяльність 3 вивчення англійської мови в інтерактивному середовищі, дозволяє виконувати завдання у форматі 24/7, надає миттевий зворотній зв'язок, містить відео та аудіо матеріали, тести та практичні завдання з граматики, лексики, читання та аудіювання. Платформа дозволяе студентам виконувати завдання в режимі онлайн в будь-який час та будь-якому місці, де є доступ до Інтернет-мережі, автоматично отримувати звіт щодо перевірки виконаних завдань, аналізувати та виправляти помилки. Інтерактивні завдання та тести значно підвищують зацікавленість студентів та заохочують до навчального процесу. MyEnglishLab дає можливість викладачу прослідкувати успішність кожного окремого студента користуючись онлайн журналом, аналізувати відсоток правильних відповідей, сильні та слабкі сторони кожного студента. Автоматична перевірка та ощінювання дозволяе викладачу самостійно обирати матеріал відповідно до потреб студента. Платформа MyEnglishLab урізноманітнюе процес навчання, формуе у студентів вміння працювати самостійно, планувати та організовувати навчання індивідуально. Цей сучасний та потужний засіб навчання змінюе традиційний підхід до вивчення іноземної мови, підвищуе ефективність та якість навчального процесу, відкриває нові можливості для роботи зі студентами в аудиторії та поза ії межами. Навчання на основі MyEnglishLab є ефективним та доцільним, спрямованим на формування комунікативної компетенції студента, забезпечуе постійне та динамічне спілкування студента та викладача, відкриває нові можливості презентації навчального матеріалу для викладача та дає змогу підвищити якість іншомовної освіти. Ключові слова: змішане навчання, MyEnglishLab, навчальне середовище, англійська мова, цифрові технології.

Tntroduction. The practice of combining (blending) different learning approaches and strategies is not new. "Traditional courses have long combined blended learning through a variety of delivery modes such as lectures, seminars, tutorials, workshops and group work to support learners with a range of opportunities." Good teachers will always use more than one method or approach in their teaching, and good learners will always combine different strategies in their learning" [7].

That's why we could state that the term "blended learning" refers to every time teachers mix different ways of presenting the content (e.g. print, audio, and video) with classroom interaction to create a supportive learning environment and provide effective teaching and learning.

But what is new is that nowadays technology is vital in offering the potential for providing more learning opportunities and better means for learners to interact with each other and learn effectively. As Anny King remarks," Technology combines all the different means within one environment: online. The online space facilitates learner-leaner interaction, encourages incidental and exploratory learning and allows learners and teachers to stay connected outside the classroom, if they so wish. Learners can benefit from the fact that space and distance do not matter anymore" [5].

The insights into the latest research. There are many definitions for blended learning. It has evolved along with the development of information and communication technology. The term originated in the business world in connection with corporate training [10], then it was employed in higher education [6] and lastly it appeared in language teaching and learning. It has become a buzzword in 
many educational establishments in recent years, usually referring to courses that employ a mix of face-to-face and on-line learning [1].

Neumeier defines that the aim of blended learning design is to find the most effective combination of learning modes for the individual learning subjects, contexts, and objectives. The focus is not to choose "the right" or "the best," "the innovative" as opposed to "the traditional"; but to create a learning environment that works as a whole [9].

Blended leaning has been implemented in education rather extensively in the past years and as predictions say, the trend towards blended learning will be increasing in the following years. The number of blended courses is predicted to conclude as many as $80-90 \%$ of all courses [2].

Marsh identifies the following strengths of blended language learning:

- provides a more individualized learning approach;

- provides more personalized learning support;

- supports and encourages independent and collaborative learning;

- increases student engagement in learning;

- accommodates a variety of learning styles;

- provides a less stressful practice foe the target language;

- help students develop valuable and necessary twenty-first century learning skills.

Nowadays the Internet helps to provide language learners with instant access to worldwide community of English language speakers, and to authentic online resources that could be a powerful medium to teach and learn languages. Social networking sites such as Facebook, You Tube, Twitter, Instagram are among the most visited on the Internet. Audio and video podcasting, blogging, virtual world activities are suited to educational users and help develop skills that are vital to successful language acquisition. Online learning and teaching environments provide fresh approaches to learning and teaching and can complement traditional face-to face learning environment. But we must not forget that the appropriate online environment should focus on learners' needs and support these needs appropriately [4].

"The choice of materials is crucial. Teachers need to evaluate educational materials such as software programs carefully and use only those materials that are methodologically sound" [7].

The purpose of the article. According to CERF (Common European Framework of Reference for Languages), students of the Department of Applied Linguistics of Lviv Polytechnic National University are supposed to have English language skills at reference level B1-B2 in their first year of study. Unfortunately, the entrance language test (External Independent Testing) shows that there is a gap between expectations and students' real knowledge of the English language. Some students find it really challenging and even stressful to achieve the required university standards. That's why we started looking for the modern, easy-accessible, motivating resource, that would be time-consuming and supportive and could improve English language skills of the students. We found that the blended learning approach through MyEnglishLab is the ideal solution to provide students with learning tools they could use in class and outside the classroom.
The main layout. Anny King identifies 8 benefits of blended learning for learners and teachers. They are (1) responding more appropriately to learning styles, (2) a deeper approach to learning, (3) more individual attention, (4) maximizing social interaction in the classroom, (5) creating confident learners, (6) access to reach interactive input, (7) getting just-in-time support, (8) encouraging discovery and fostering autonomy.

1. A blended learning approach allows teachers respond more easily to learners' different styles by maximizing the strengths of each environment. Students can decide themselves when and where to study. The role of the teacher is to help students develop the skills they require to work independently and to take on responsibility for their own learning. While preparing programs of study the teacher should consider different learning styles as learners can choose visual/aural texts in preference to written texts or they can watch a video or listen to audio reading a transcript at the same time.

2. Learning online students can choose their own pathway according to their needs and interests, they can go back and revise the learning content according to their time-management. They read or watch a video without feeling rushed, having time to reflect on a text or a video. This helps them promote better understanding and deeper learning in the most convenient way. Such learning environment is friendly, easily accessible and attractive to the learner.

3. Blended learning helps teachers give all learners the attention they deserve. Any teacher in any classroom feel that there are faster and slower learners. By developing a course that will take into account learners' needs more closely the teacher could encourage students' engagement and achieve the best learning outcomes.

4. Blended learning can provide opportunities for genuine communication in the classroom. "Blended learning does not mean a reduction of face-to-face class time. On the contrary, it requires greater participation of learners, greater interaction with content and an overall greater level of engagement" [3].

5 . The fear of speaking in class could be a significant obstacle to learning a second language as learners are concerned of making mistakes. "The more exposure students have to different contexts, voices, and accents, the more confident they will feel in the "real world" use of language" [7].

6. Blended learning offers rich interactive input (authentic video, audio, texts) relevant to learner's needs and interests. For lower level learners the material could be selected by the teacher and highlevel learners may discover the material when surfing the internet themselves. This input help teachers develop a course that can correspond to different learning styles.

7. Getting just-in-time support is crucial for learning. In a blended learning approach, technology offers instant feedback giving learners many tools at their disposal. "The combination of audio, video, animation, text and links immerse them deeper into the language" [3].

8. Blended learning approach encourage students to work autonomously and independently. Students are flexible to choose the time they study, making 


\title{
MyEnglishLab
}

\section{\begin{tabular}{l|ll}
2 & 2.4 SCENARIO: Sparrow Hill Wind Farm & Switch to Student view
\end{tabular}}

\author{
Pronunciation
}

Listen and practise saying the following phrases.

1

Listen You have a point.

2

- Listen I am interested to know more about it.

3

Listen I would go along with you there.

4

Listen That is very true.

5

Listen You are absolutely right.

6

Listen I would like to know how you discovered that.
Record Playback

Record DPlayback

Record Playback

Record Playback

Record Playback

Record Playback

Record Playback

Figure 1. Pronunciation Exercise

their own decisions and taking responsibility for their own learning process. "A blended approach, when its elements are combined effectively, helps both teacher and learner fulfil their ultimate roles" [5].

MyEnglishLab is considered to be one of the most powerful tools for blended learning in global academic society. It is an online component designed to complement Pearson ELT textbooks: Choices, Speakout, Language Leader, Market Leader and etc. MyEnglishLab components can replace traditional Pearson paper workbook, helping students and teachers get more from the course. MyEnglishLab activities replicate the content students complete in a workbook, but in an interactive and engaging environment. Students can access all their content through Pearson English Portal in one place and receive instant feedback on each task. They can watch videos, listen to audio and even record their own voices online (Figure 1). This vast range of activities will help them build their confidence and improve on their mistakes.

MyEnglishLab is a great contribution to blended learning approach.

Firstly, enriched learning through students' engagement [11]. Interactive activities, tasks and tests raise students' interests and engage them in the learning process. The more engaged they are, the better results they get. Extra hints and tips that the platform provides encourage and support learning. Each activity is built into a lesson plan and helps students practice speaking, listening, reading and writing (Figure 2 ).

Secondly, a blended learning approach allows teachers to be more informed about students' strengths and weaknesses. Each activity that students complete is recorded on the MyEnglishLab Grade book, making it easy to see students' progress (Figure 3). It can be viewed for the whole class or individual students. The teacher can also find out which errors are common among the students, using the Common Error Report. With this information, the teacher can focus valuable class time on the areas that are needed the most. My English Lab enables to mark students' homework assignments automatically. The time saved by automatic correction helps the teacher to manage and personalize the course material according to students' needs and preferences.

Thirdly, My English Lab has a range of tools to make classroom management simple and flexible. You can communicate with your students easily through email notifications and online messaging in a safe and secure environment. Students can access all the activities when they are online anytime and anywhere. The teacher can create course, groups, hide/show/assign content, share course with colleagues and even download the video activities.

Students were asked to discuss both the advantages and disadvantages of MyEnglish Lab. They liked the possibility of getting connected easily. They 


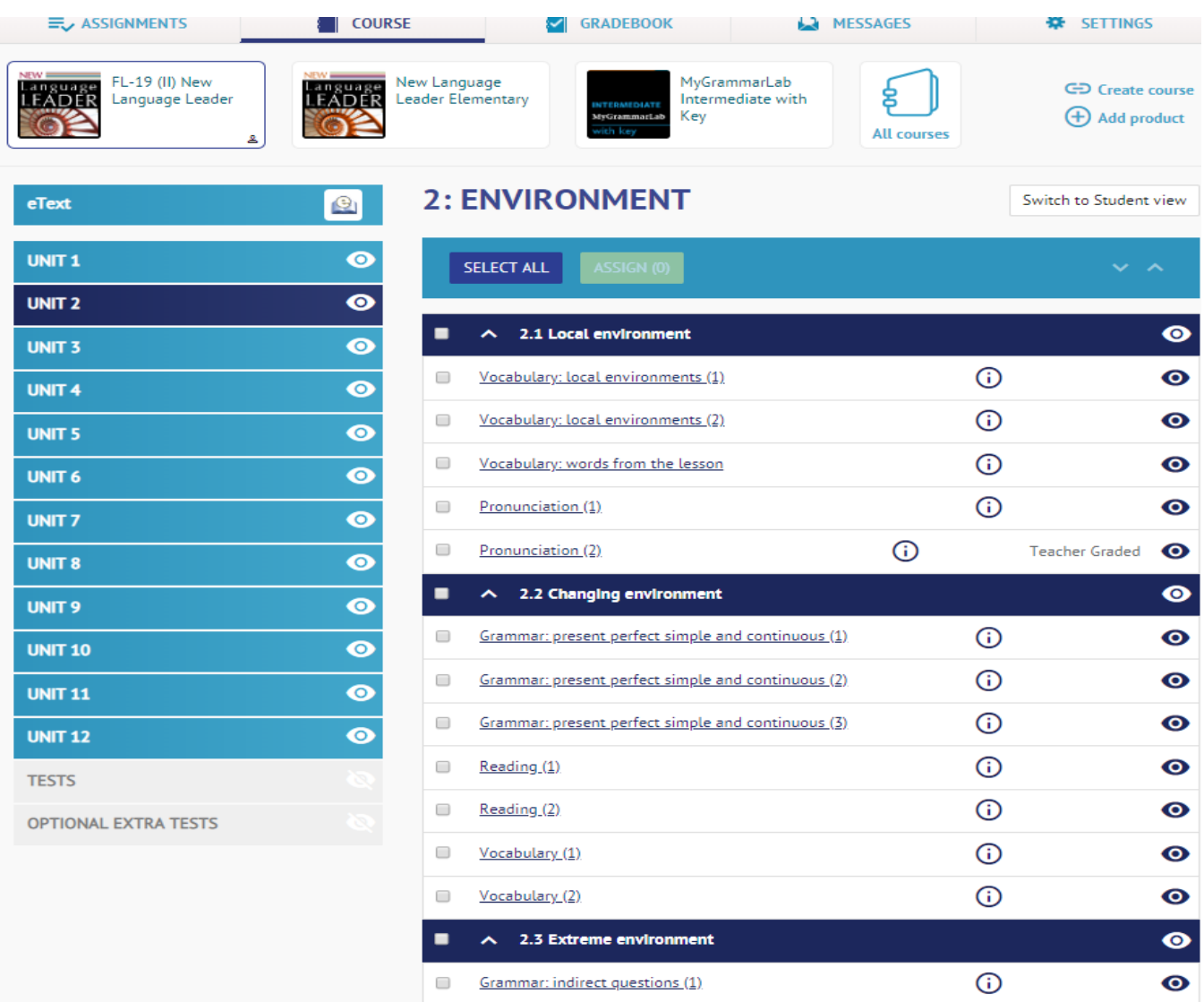

Figure 2. Lesson Plan Activities

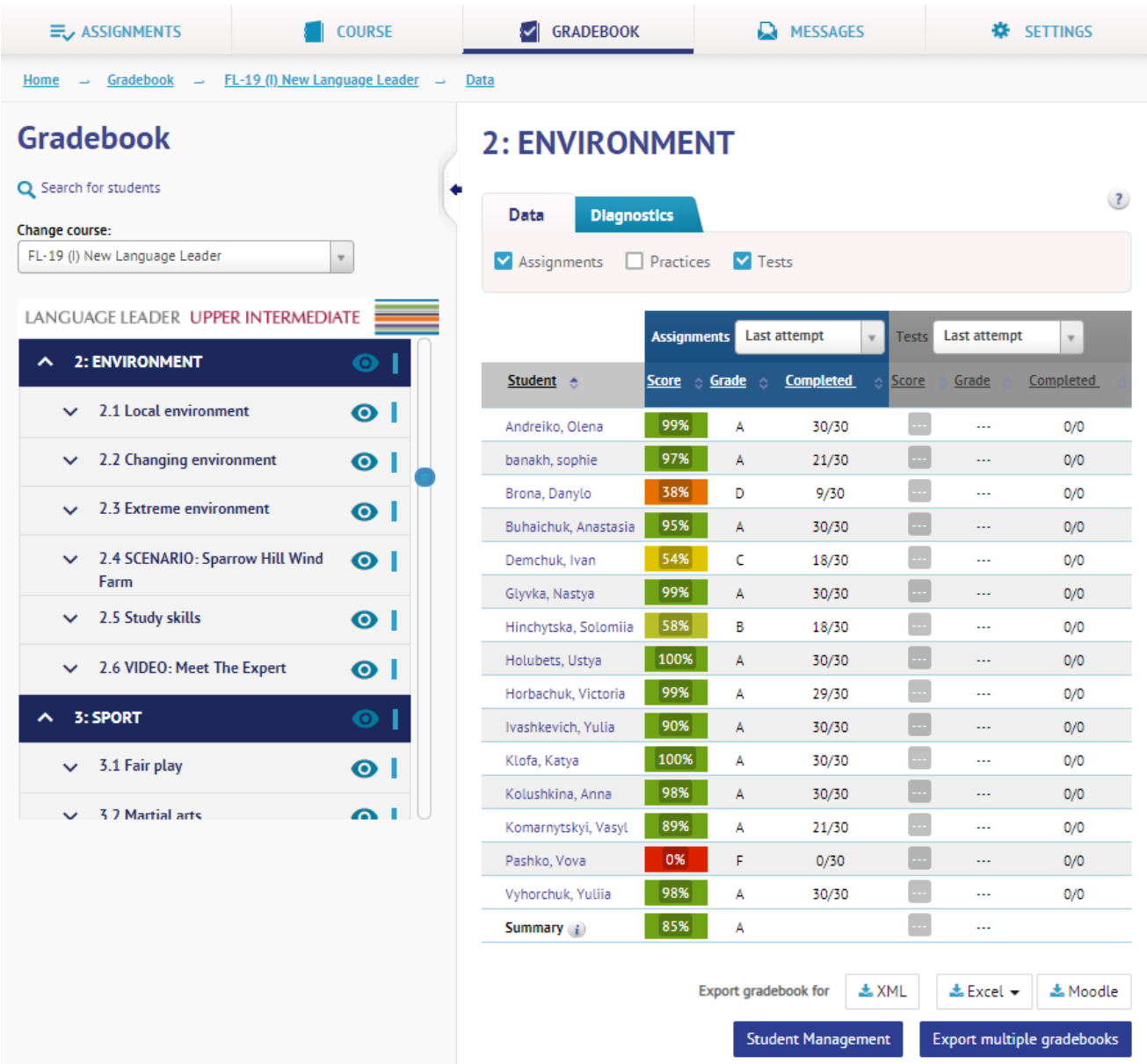

Figure 3. Students' Performance 
appreciated timely feedback of their online work, they mentioned their progress in specific language skills, such as listening, reading, vocabulary and grammar.

Conclusion. The Department of Applied Linguistics, Lviv Polytechnic National University, demands students to master the English language according to their field of study, to obtain a professional and academic vocabulary and language fluency. The blended learning approach proves to be an efficient way of implementing these demands. MyEnglishLab, chosen as a part of blended learning approach, is, undoubtedly, an attractive and up-to-date component of modern education. Incorporating technology into the learning and teaching process is beneficial for teachers and students. Different digital tools that are provided by MyEnglishLab, engage students in authentic context and learning environment. Students using MyEnglishLab in their English courses reach better results in grammar, reading and listening, vocabulary in comparison with students using paper-based material. These aspects contribute greatly to students' motivation to study and improve English language proficiency for everyday use.

\section{References:}

1. Bonk, C.J., \& Graham, C.R. (2012). The handbook of blended learning: Global perspectives, local designs. San Francisco, CA: Pfeifer Publishing.

2. Graham, C.R. (2006). Blended learning systems: definition, current trends, and future directions.

3. Cavage, C. (2012). Why blended learning may be just what you have been looking for. Pearson Education, Inc.

4. Colpaert, J. (2004). From courseware to coursewear? Computer Assisted Language Learning, 17 (3-4), $261-266$.

5. King, A. (2016). Blended language learning: Part of the Cambridge Papers in ELT series. Cambridge: Cambridge University Press.

6. MacDonald, J. (2006). Blended learning and online tutoring. Aldershot, Hampshire: Gover.

7. Marsh, D. (2012). Blended Learning: Creating Learning Opportunities for Language Learners. Cambridge: Cambridge University Press.

8. MyEnglishLab's manual description. Pearson ELT. Available at: https://www.pearsonelt.com/myenglishlab.html/ (accessed on February 11, 2020)

9. Neumeier, P. (2005). A closer look at blended learning - parameters for designing a blended learning environment. ReCall, 179(2), 163-178.

10. Sharma, P., \& Barret, B. (2007). Blended Learning. Oxford, UK: Macmillan.

11. Vymetalkova D., \& Milkova E. (2019). Experimental Verification of Effectiveness of English Language Teaching UsingMyEnglishLab. Available at: https://www.mdpi.com/journal/sustainability/ (accessed on February 2, 2020). 